\title{
CYTOCHEMICAL DETECTION OF CYTOCHROME OXIDASE ACTIVITY IN BACTERIA
}

\author{
R. G. COOPER \\ Bacteriology Department, Adelaide Children's Hospital, \\ North Adelaide, South Australia \\ Plate XX
}

THE oxidase reaction, which has earned a well-established place in the identification of Gram-negative bacteria, is customarily applied to a culture. However, apart from having some academic interest, the cytochemical detection of oxidase activity in the bacterial cell might assist in the rapid presumptive identification of some of the bacteria that occur in wounds, exudates, cerebrospinal fluids and blood cultures. The only bacteriological reference that I have been able to find to the cytochemical detection of oxidase activity is that of Dietrich and Liebermeister (1902, cited by Gordon and McLeod, 1928) who, after adding dimethyl$p$-phenylenediamine $\mathrm{HCl}$ and $\alpha$-naphthol to a hanging drop suspension of Bacillus anthracis, saw blue granules in the rods. The present paper describes the use of a cytochemical method for the detection of cytochrome oxidase that has been adapted to detect oxidase activity in bacteria.

\section{MATERIALS AND METHODS}

Two hundred and thirty-eight strains of various bacteria were examined cytochemically for oxidase activity. These strains had been identified by standard means, including Kovacs' (1956) test for oxidase in the cultures. Bacteria were examined after aerobic incubation for $18-24 \mathrm{hr}$ at $37^{\circ} \mathrm{C}$ on horse blood agar except that "chocolate" (heated blood) agar was used for Haemophilus influenzae and Neisseria gonorrhoeae, Bordet-Gengou agar for Bordetella pertussis, and anaerobic incubation on blood agar for Bacteroides species and Clostridium welchii.

The organisms were suspended in distilled water and allowed to dry on clean slides. The following staining technique was modelled on one described by Burstone (1959). A reagent mixture was freshly prepared by dissolving $25 \mathrm{mg}$ of a coupler, 1-hydroxy2-naphthoic acid, and $25 \mathrm{mg}$ of an amine, N-phenyl-p-phenylenediamine (Variamine Blue RT Base, Sigma) in $1 \mathrm{ml}$ of ethanol, then adding $35 \mathrm{ml}$ of distilled water followed by $15 \mathrm{ml}$ of $0 \cdot 2 \mathrm{M}$ Tris buffer at $\mathrm{pH} 7 \cdot 4$. The slides were incubated for $60 \mathrm{~min}$. at room temperature $\left(28^{\circ} \mathrm{C}\right)$ in the reagent mixture, transferred directly to 2.5 per cent. cobalt acetate, $\left(\mathrm{CH}_{3} \mathrm{COO}\right)_{2} \mathrm{Co} .4 \mathrm{H}_{2} \mathrm{O}$, in 4 per cent. formaldehyde in water, and left for $30 \mathrm{~min}$. The slides were washed in tap water, counterstained in 0.5 per cent. malachite green for $5 \mathrm{~min}$., dried in air and then examined, without coverslip, under immersion oil (Gurr's Microil). Swabs from clinical material were smeared on slides and stained in a similar way except that incubation in the reagent mixture was for $120 \mathrm{~min}$.

Two hundred and fifty-five swabs of clinical material from the diagnostic laboratory were examined. Smears were examined by Gram staining and by oxidase staining. The cultural findings were obtained independently by the staff of the Bacteriology Department 
and the results correlated after the decisions had been recorded for the smears. The clinical sites or sources of the specimens and the numbers studied were as follows: ear 85 ; cough swab or sputum 42; abscess 30 ; wound 38 ; spleen or lung (post mortem) 12; peritoneal cavity 10 ; cerebrospinal fluid 7 ; pleural space 3 ; vagina 3 ; blood culture 2 ; antrum 1 ; joint 1.

Technical factors that influenced the staining reaction were studied in six strains of Pseudomonas aeruginosa, two strains of Escherichia coli and two strains of Neisseria pharyngis. Cultures were examined from nutrient and blood agar after incubation at $37^{\circ} \mathrm{C}$ for 4,6 , $12,18,24,48$ and $60 \mathrm{hr}$. For the Gram-negative rods, oxidase-staining reactions were compared after growth in peptone water*, Tryptone broth, Brain Heart Infusion Broth (Oxoid Ltd, London) and Cystine Trypticase Broth (Baltimore Biological Laboratory, USA) for $18 \mathrm{hr}$ at $37^{\circ} \mathrm{C}$.

In the case of the reagent mixture, the influence of buffer, amounts of coupler and amine of 10,25 and $50 \mathrm{mg}$, incubation periods of $5,10,15,30,60,90,120,150$ and $180 \mathrm{~min}$., and incubation at $37^{\circ} \mathrm{C}$ and $28^{\circ} \mathrm{C}$, and the role of coupler were studied. The role of cobalt acetate, the influence of saline and the effect of adding cytochrome $\mathrm{C}$ (horse heart type 3 , Sigma) on the oxidase staining reaction were examined. Parallel series of smears were fixed (i) in 4 per cent. formaldehyde in water, (ii) in ice-cold buffered formaldehyde at

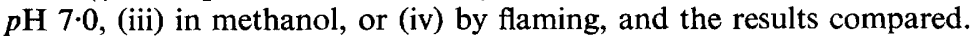

\section{RESULTS \\ Oxidase-staining reactions with bacterial cultures}

Table I shows the results obtained with the oxidase staining reaction when bacterial cultures were examined. Without exception the appearances of pseudomonads, Plesiomonas shigelloides (C27 group), aeromonads and Bordetella bronchiseptica were very striking after oxidase staining. A typical rod had distinct circular black granules at either pole filling out the width of the cell. Some cells had only one granule; others, particularly the long rods, had additional black transverse segments that gave the cell a beaded appearance. In some smears nearly all cells showed oxidase granules, but often a smaller proportion stained positively (figs. 1 and 2). Alkaligenes faecalis was also distinctive, but tended to give smaller oxidase granules, an appearance consistent with the observations of Gaby and Free (1958) that Alkaligenes gave a weaker oxidase reaction by their test on cultures than did Pseudomonas.

In contrast, bacteria belonging to the Enterobacteriaceae did not show this staining reaction but gave a uniform or, more commonly, bipolar staining, with malachite green (fig. 3). One strain of $E$. coli showed tiny doubtful granules at either pole, but there was no confusing it with an oxidase-positive rod.

Neisseria species showed a very strong oxidase staining reaction. The strains consisted of two isolates of $N$. gonorrhoeae and 13 of $N$. pharyngis and in every case the smear showed that virtually all cells had become jet black or had large black granules occupying most of the cell.

The staphylococci that were examined consisted of 37 strains of Staph. aureus and seven strains of coagulase-negative staphylococci that were not identified further.

It was found possible to alter the sensitivity of the oxidase stain, but Kovacs' reaction on the culture seemed to be more sensitive than the method finally

\footnotetext{
* 1 per cent. Bacto-Peptone (Difco) in distilled water.
} 
employed, as Bord. pertussis and $H$. influenzae were judged to be oxidasenegative in the smear.

TABLE I

Oxidase reaction results obtained with various bacteria by staining method and by Kovacs' method

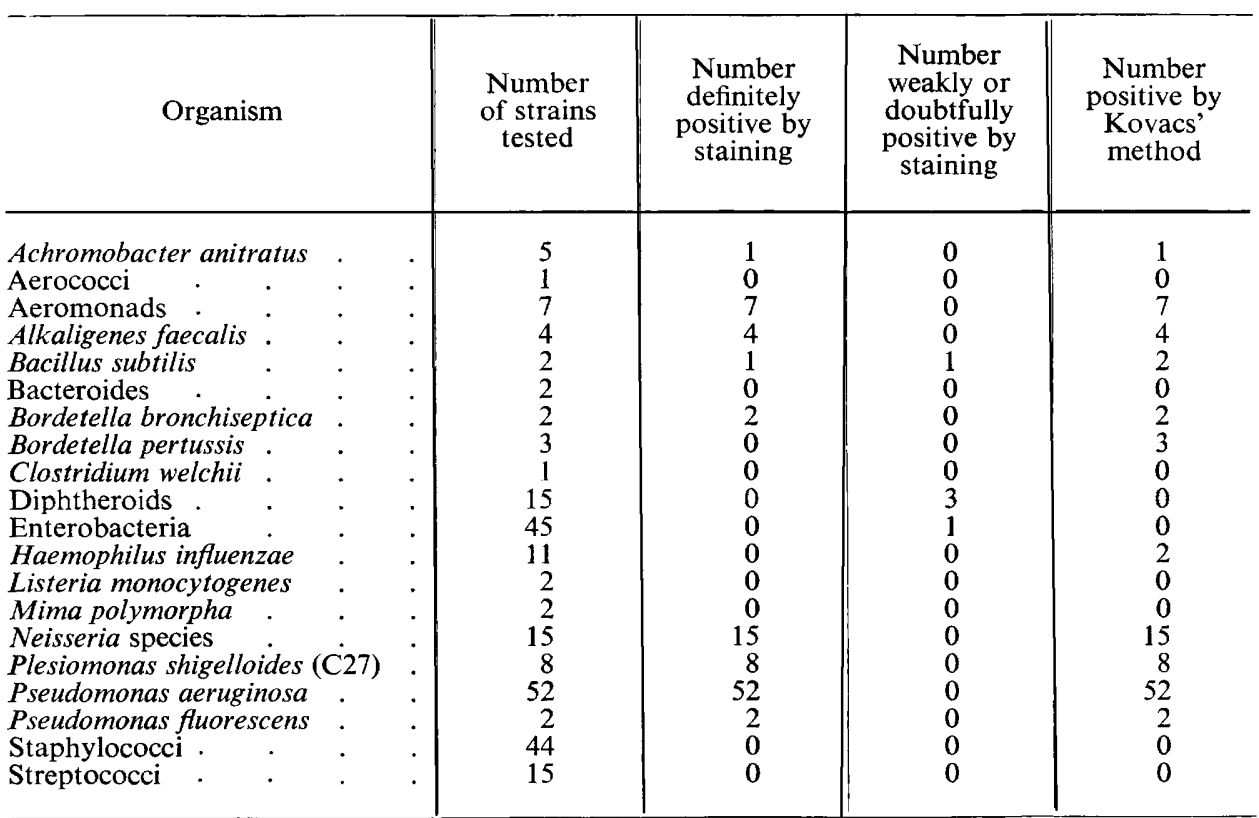

TABLE II

Oxidase staining reactions and cultural findings obtained with 255 swabs from clinical material

\begin{tabular}{|c|c|c|c|c|}
\hline \multirow[b]{2}{*}{$\begin{array}{l}\text { Category of smear and number } \\
\text { examined }\end{array}$} & \multicolumn{4}{|c|}{ Number of specimens with cultural findings of } \\
\hline & no growth & $\begin{array}{l}\text { Ps. } \\
\text { aeruginosa }\end{array}$ & $\begin{array}{c}\text { Alk. } \\
\text { faecalis }\end{array}$ & $\begin{array}{c}\text { oxidase- } \\
\text { negative } \\
\text { bacteria } \\
\text { (Kovacs' test) }\end{array}$ \\
\hline $\begin{array}{l}\text { No organisms in smear }(91) \\
\text { Oxidase-negative staining bacteria in }\end{array}$ & $\begin{array}{r}22 \\
6\end{array}$ & $\begin{array}{r}5 \\
10\end{array}$ & $\begin{array}{l}2 \\
0\end{array}$ & $\begin{array}{r}62 \\
109\end{array}$ \\
\hline $\begin{array}{l}\text { Oxidase-positive staining bacteria in } \\
\text { smear (39) }\end{array}$ & 0 & 25 & 3 & 11 \\
\hline
\end{tabular}

Six strains of Candida albicans were examined after growth on blood agar and all showed oxidase granules in the cells.

\section{Oxidase stains on clinical material}

Attention was directed mainly to the presence or absence of oxidase-positive bacteria in the smears, and table II correlates the oxidase stain and cultural 
findings in the 255 specimens. There were five smears in which yeasts were seen and four of these smears showed oxidase-positive granules in the fungi. Candida species were grown from all five specimens and from 15 others in which yeasts were not seen in the direct smears.

The 182 specimens from which oxidase-negative bacteria were cultured contained a variety of bacteria that included members of Enterobacteriaceae in 34 specimens, staphylococci in 81 specimens, streptococci in 42 specimens and $H$. influenzae in 32 specimens. In the ten specimens from which Ps. aeruginosa was cultured, yet oxidase-positive bacteria were not seen in the direct smears, Gram-stained direct smears showed Gram-negative rods and the oxidase stain was therefore regarded as a failure in these cases.

There were 39 specimens in which oxidase-positive bacteria were seen in the direct smear. In three specimens, oxidase granules were seen in cocci and only Gram-positive cocci were seen in the Gram-stained smear. Staph. aureus was cultured from all three specimens and, in addition, Streptococcus pyogenes was grown once. In another specimen, tiny oxidase granules were seen in rods; the Gram stain showed diphtheroids and Gram-positive cocci, but Staph. aureus and Strept. pyogenes were grown. A smear of an ear swab showed Gram-positive cocci and small Gram-negative coccobacilli morphologically resembling Haemophilus species. Oxidase granules were seen in the cocci and an occasional rod showed a tiny granule. The culture grew Staph. aureus and $H$. influenzae. An appendix abscess showed Gram-negative rods and Grampositive cocci in chains. Rare, doubtful, tiny granules were seen in the rods. The culture grew E. coli, Clostridium welchii, Bacteroides species and anaerobic streptococci. A smear prepared from an ear swab showed diphtheroids and Gram-positive cocci. Some small oxidase granules were seen in long rods. Culture grew Strept. pneumoniae and Staph. aureus.

In the remaining 32 specimens, definite oxidase-positive rods were seen and the Gram stain showed Gram-negative rods. In this group, 28 specimens grew Ps. aeruginosa or Alk. faecalis. The other four specimens are regarded as failures although two contained diphtheroid organisms. The exudate from an inflamed wound infected with Ps. aeruginosa often presented a typical appearance in which many strongly oxidase-positive rods were seen in the exudate (fig. 4).

\section{Illustrative case reports}

The technique has had a place in the rapid, presumptive diagnosis of pseudomonas infection.

Case 1. A girl was admitted at the age of 1 day with the features of intestinal obstruction. At operation a membrane obstructed the jejunum and there was torsion of the small intestine. In all, five operations were performed in an attempt to cure the congenital defects and to deal with various complications sustained by this patient. In the course of her illness she had an episode of klebsiella septicaemia and klebsiella wound infection, but she had been singularly free of pseudomonas infection. However, 2 days before her death the wounds in her abdomen started to bleed and on the day before death the wounds became black. The Gram stain showed many polymorphs and Gram-negative rods and the oxidase stain showed strongly oxidase-positive rods forming most of the flora. She was diagnosed on 
this evidence as having significant pseudomonas infection and treatment was instituted. She died the next day at the age of 44 days. The cultural and post-mortem findings confirmed pseudomonas septicaemia.

Case 2. A boy aged $2 \mathrm{yr}$ was admitted with a history of pallor and bruising for $2 \mathrm{wk}$. He had a swollen, bruised left big toe. The haematological findings were of an acute lymphoblastic leukaemia. Blood culture had been taken on admission. Gram stains of some scanty exudate from the big toe showed Gram-positive cocci only, and Staph. aureus was cultured. On his 8th day in hospital a dark, flat, haemorrhagic lesion, $3 \mathrm{~cm}$ in diameter, appeared on the left calf. The left toe was apparently now gangrenous. The platelet count was low $\left(12,000\right.$ per $\left.\mathrm{mm}^{3}\right)$. It had always been considered possible that the patient had pseudomonas septicaemia, but the blood culture taken on admission had not grown any organisms and it was possible that the skin lesions were staphylococcal and there had been bleeding into them. A blood culture taken, however, on the 8th day after admission grew a motile Gram-negative rod on the 9th day. An oxidase stain showed definite oxidase granules in the rods and the presumptive diagnosis of pseudomonas septicaemia was made and treatment for this started. The next day the isolate from the blood culture was confirmed as Ps. aeruginosa. The patient died on his 12 th day in hospital.

\section{Factors affecting the oxidase-staining reaction}

Cultural conditions. Ps. aeruginosa grown on nutrient agar for 18-24 hr had intracellular oxidase granules that were similar but less numerous than those seen when strains were grown on blood agar. Strains grown on blood agar soon lost their granules as the culture aged. Granules seemed to be most numerous in 4-hr-old cultures; at $48 \mathrm{hr}$, only a small proportion of the cells had granules. After $60 \mathrm{hr}$, oxidase granules were rare. In the bacteria cultured on nutrient agar there was a slight tendency for the granules to persist longer, but in cultures from a variety of broths tested-peptone, tryptone, brain heart infusion and cystine trypticase-there seemed to be no difference in the oxidase-staining reaction.

Cell damage. After incubation in the reagent mixture of coupler and amine, the bacterial cells seemed to suffer variable degrees of structural damage so that the outline of the cell became indefinite, and the affinity for the counterstain was reduced. When Gurr's Microil was applied to the slides for from $15 \mathrm{~min}$. to $1 \frac{1}{2} \mathrm{hr}$ the cell outline became clearer and this offset some of the apparent damage. This cell damage was particularly a problem with Ps. aeruginosa. Incubation in the reagent mixture for longer than $60 \mathrm{~min}$. tended to increase the cell damage and certainly reduced the affinity for the counterstain. Omission of the coupler from the reagent mixture made no difference.

Some observations that have been made on the effect of Tris buffer on Ps. aeruginosa appear to be relevant. Asbell and Eagon (1966) showed that the cell wall damage and the lethal effects of ethylene-diaminetetra-acetate on Ps. aeruginosa were accentuated by Tris buffer. Cox and Eagon (1968) showed that when the isolated cell walls of Ps. aeruginosa were incubated in Tris buffer at $p \mathrm{H} 8 \cdot 0$ the proportion of cell wall by dry weight that went into solution was of the order of 14 per cent. as compared with 9 per cent. when the cell walls were incubated in water alone. Consequently the effect of replacing the Tris buffer with a phosphate buffer $\left(\mathrm{K}_{2} \mathrm{HPO}_{4}\right)$ at $p \mathrm{H} 7 \cdot 4$ was tried, but cell damage 
and affinity for the counterstain were not altered. Incubation in coupler and amine dissolved in water with no added buffer led to very poor staining of the oxidase granules.

Roles of coupler, amine and cobalt acetate. Cobalt acetate was not necessary for the development of visible oxidase granules in the cells, but chelation of cobalt into the dye complex gave greater stability to the preparation. Thus if cobalt acetate was omitted the granules started to fade in 1-2 hr and there was serious fading after $24 \mathrm{hr}$. The use of cobalt acetate gave dye complexes that were stable for up to 10 days, the maximum period the slides were kept. Oxidase granules developed in the cells when the coupler was omitted from the reagent mixture and the amine was used alone, but the complexes were not as distinct, and the coupler did improve the staining reaction.

Concentrations of coupler and amine in reagent mixture. The concentrations used by Burstone for the staining of oxidase granules in tissue cells were $10 \mathrm{mg}$ of each reagent in a volume of $51 \mathrm{ml}$. This concentration produced inconsistent and unsatisfactory staining of oxidase granules in bacteria. When amounts of $50 \mathrm{mg}$ of each reagent were used, oxidase staining was also poor. The optimum amount was found to be $25 \mathrm{mg}$.

Period of incubation in reagent mixture. For optimum development of oxidase granules in Ps. aeruginosa, incubation in the reagent mixture for $60 \mathrm{~min}$. at room temperature $\left(28^{\circ} \mathrm{C}\right)$ was required. Longer incubation of smears of cultures seriously reduced bacterial affinity for the counterstain. However, optimum staining of known Ps. aeruginosa in an exudate usually required $120 \mathrm{~min}$. Incubation for $180 \mathrm{~min}$. tended to produce in $E$. coli small granules at either pole. These granules were quite distinct from the large granules seen in Ps. aeruginosa. For all bacteria, incubation at $37^{\circ} \mathrm{C}$ did not improve the staining reaction.

Effect of saline and cytochrome $C$. The oxidase reaction is mediated indirectly through cytochrome $\mathrm{C}$; saline inhibits the oxidase reaction in tissues by washing out cytochrome $\mathrm{C}$ (Burstone). The addition of horse heart cytochrome $\mathrm{C}$ to the reagent mixture did not accentuate the staining reaction. This is not surprising as Yamanaka and Okunuki (1963) have crystallised from Ps. aeruginosa a cytochrome C oxidase that has particular specificity for pseudomonas cytochrome $\mathrm{C}$ and scarcely any for mammalian cytochrome $\mathrm{C}$. Bacteria suspended in saline gave poorer staining reactions than when distilled water was used.

Method of fixation of smears. Fixation by heat produced less intense oxidase staining in Ps. aeruginosa, but did not abolish the reaction. Fixation in methanol inhibited the staining reaction. Air-drying the smears seemed to be as good as fixing smears in 4 per cent. formaldehyde in water. With bacterial cultures there seemed to be no particular advantage in fixing in formaldehyde. A trial was

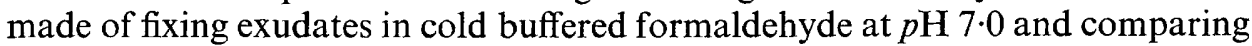
them with air-dried unfixed smears. No consistent pattern emerged. Sometimes fixation produced a more distinct preparation and sometimes the unfixed slide was clearer. 
DETECTION OF CYTOCHROME OXIDASE

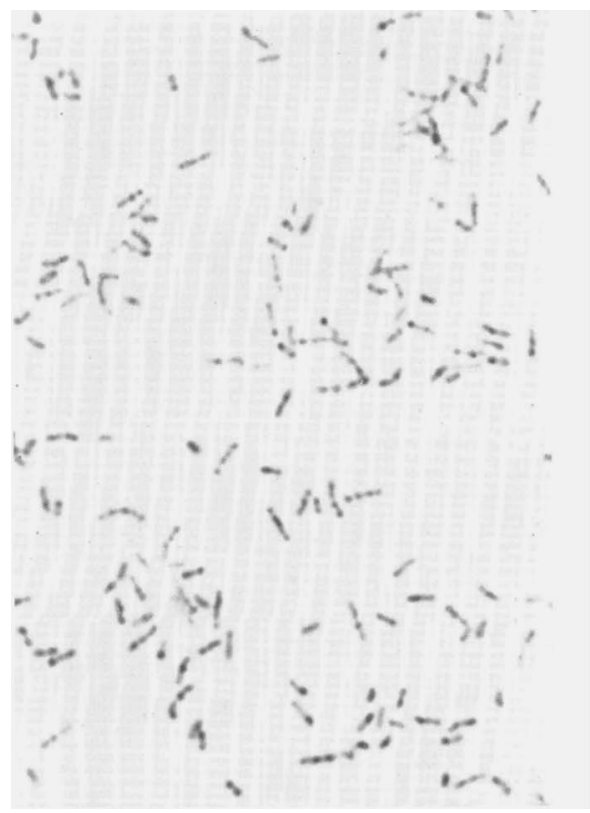

FIG. 1.-Pseudomonas aeruginosa showing oxidase granules in rods. Oxidase stain (OS). $\times 1500$.

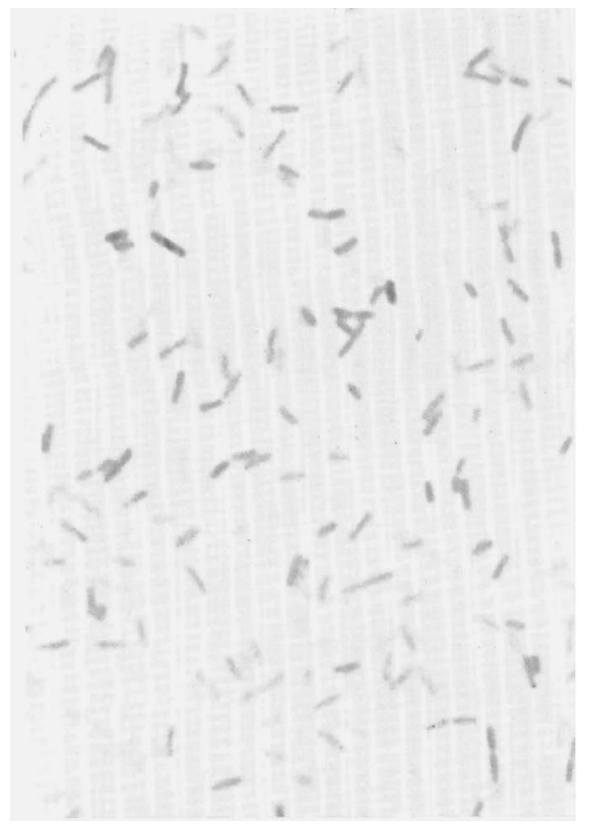

FIG. 3. - Klebsiella aerogenes. Oxidase granules absent. OS. $\times 1500$.

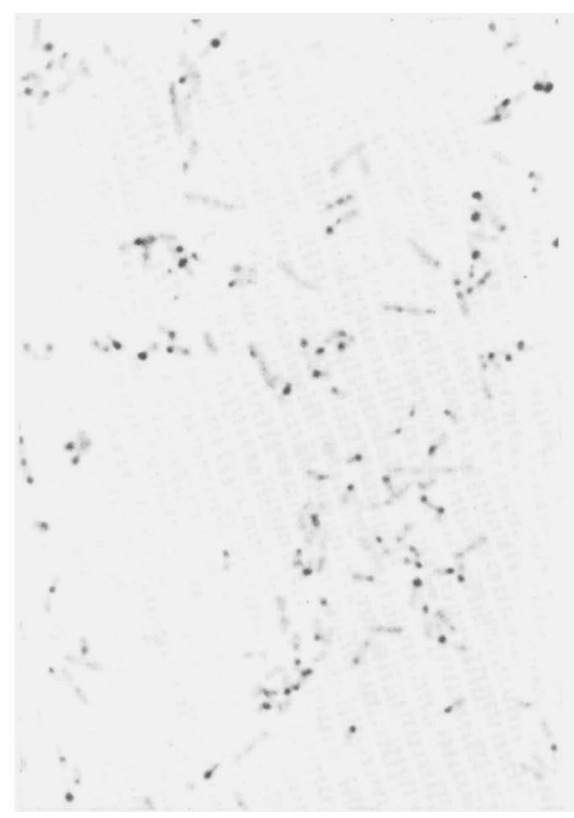

FIG, 2.-Plesiomonas shigelloides showing oxidase granules in rods. OS. $\times 1500$.

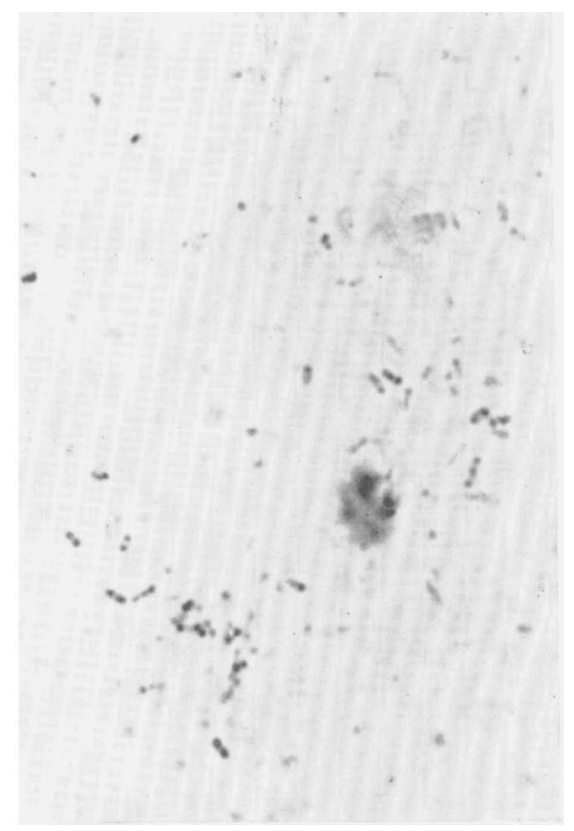

FIG. 4.-Exudate from wound infected with Ps. aeruginosa. OS. $\times 1500$. 


\section{Discussion}

Gordon and McLeod (1928) in their classical description of the oxidase reaction in bacteriology described how smears of oxidase-positive colonies showed no marked staining of the cells and the reaction was thought to be a surface one. My early efforts to stain pseudomonas cells with tetramethyl- $p$ phenylenediamine and $\alpha$-naphthol were equally disappointing, but with new substrates, which are credited with rapid action, more intense dye production, greater permanency and sharper localisation (Burstone, 1959), I have been successful in demonstrating intracellular oxidase activity.

In tests with bacterial cultures it has been possible to obtain staining reactions that, in the main, are consistent with Kovacs' (1956) test. With Gramnegative rods there has been no difficulty in distinguishing oxidase-positive from oxidase-negative cells in the smear.

Corynebacterium species are held to be oxidase-negative by conventional testing (Wilson and Miles, 1964), but diphtheroids in smears of exudates occasionally showed small oxidase granules. The cultured diphtheroids that were tested were oxidase-negative by Kovacs' method. Some coagulasenegative staphylococci give a slow positive reaction with Kovacs' test, but Staph. aureus seems to be consistently negative (Steel, 1962). In smears of a few exudates, cocci containing small oxidase granules were found. The smears showed Gram-positive cocci, morphologically resembling staphylococci, and from some of these exudates Staph. aureus alone was cultured. However, these specimens came from sites such as ear, vagina and sputum in which coagulase-negative staphylococci may have accounted for the appearances in the oxidase smear.

Few would dispute that the presumptive identification of bacteria in direct smears of clinical material is of help to the clinical bacteriologist. The smear may provide essential diagnostic evidence, it may assist in interpreting the cultural findings and it may allow a rapid presumptive diagnosis so that specific therapy of immediate benefit to the patient can be instituted. Immunofluorescence techniques have obvious attractions in this context, but there are difficulties in producing specific antisera and avoiding cross-reactions.

The presumptive cytological identification of bacteria by the utilisation of characteristic enzymic properties of certain bacteria seems to be a justifiable attempt to assist the diagnostician. Oxidase staining has been useful in this laboratory in the presumptive identification of certain diseases, particularly pseudomonas infection. The method does sometimes fail. Failure to recognise pseudomonas organisms by this procedure on direct microscopy may be due to the presence of an insufficient number of cells in the direct smear or the cells may be too old to give a sufficiently vigorous oxidase staining reaction. The method may have other applications in clinical bacteriology.

\section{SUMMARY}

The use of 1-hydroxy-2-naphthoic acid and N-phenyl-p-phenylenediamine allowed oxidase activity to be detected cytologically in bacteria. The 
demonstration of this activity seemed to be correlated in the main with known oxidase activity of these bacteria as determined by more conventional means. The method was applied to the presumptive identification of oxidase-positive bacteria in direct smears of clinical material, and this procedure sometimes assisted in the presumptive diagnosis of infectious disease due to these oxidasepositive bacteria.

Of 125 clinical specimens with only oxidase-negative bacteria on the direct smear, there were ten ( 8 per cent.) from which oxidase-positive bacteria Pseudomonas aeruginosa) were cultured. In 39 clinical specimens that showed oxidase-positive bacteria on direct microscopy, there were 32 in which a presumptive diagnosis of pseudomonas or alkaligenes infection was made; Ps. aeruginosa or Alkaligenes faecalis was cultured from 28 ( 85 per cent.) of these 32 specimens.

This work was made possible and was supported by a generous grant from Beecham Research, Pharmaceutical Division of Beecham Australia. I gratefully acknowledge the assistance of Miss Juliet Thompson in this investigation.

\section{REFERENCES}

Asbell, Mary, and Eagon, R. G. . . 1966. J. Bact., 92, 380.

Burstone, M. S. . . . . . . . 1959. J. Histochem. Cytochem., 7, 112.

Cox, S. T., JR, ANd EAGon, R. G. . . 1968. Canad. J. Microbiol., 14, 913.

GABY, W. L., AND FReE, E. . . . . 1958. J. Bact., 76, 442.

Gordon, J., AND MCLeod, J. W. - . 1928. J. Path. Bact., 31, 185.

Kovacs, N. . . . . . . . . . 1956. Nature, Lond., 178, 703.

Steel, K. J. . . . . . . . . . . . 1962. J. Appl. Bact., 25, 445.

Wilson, G. S., AND Miles, A. A. . . 1964. Topley and Wilson's Principles of bacteriology and immunity, 5th ed., London, p. 588.

Yamanaka, T., and Okunuki, K. . . 1963. Biochim. biophys. Acta, 67, 379. 